\title{
Analysis of water losses in two selected water distribution systems
}

\author{
Anna Musz-Pomorska ${ }^{*}$, Matgorzata Iwanek $^{1}$, Katarzyna Parafian $^{2}$, and Katarzyna Wójcik ${ }^{2}$ \\ ${ }^{1}$ Faculty of Environmental Engineering, Lublin University of Technology, ul. Nadbystrzycka 40B, \\ 20-618 Lublin, Poland, phone: +48 815384481 \\ ${ }^{2}$ Graduate of the Lublin University of Technology
}

\begin{abstract}
The analysis of water losses should precede the decisions on repairing or modernizing a water network. Water balance and water losses indicators established by the International Water Association (IWA) standards can constitute the basis for the analysis. The methods recommended by IWA are gaining increasing popularity in many countries, including Poland. The aim of the paper is the analysis and comparison of water losses in two middle-sized water distribution systems during the period of 10 years. The compared networks are similar in respect to many parameters, including water intensity indicator value (circa $48 \mathrm{~m}^{3} / \mathrm{d} / \mathrm{km}$ ). Analyses were conducted on the basis of water losses indices recommended by IWA, such as Real Losses Level per connection per day $(R L L)$, Non-Revenue Water Level $(N R W L)$ and Infrastructure Leakage Index $(I L I)$. The results indicated that water losses in both systems are lower than in the literature data for other similar networks.
\end{abstract}

\section{Introduction}

The problem of water losses in distribution systems is one of the main concerns of the water systems managers both in Poland and around the world. It is commonly known that real losses are caused mainly by leakages as a result of water network breakages and failures. Therefore, it is not surprising that many scientists use the most recent technological and scientific developments to work out efficient methods for limitation of failures and their results [e.g. 1-8]. However, it should be emphasized that real losses of water cannot be eliminated totally [9].

International Water Association (IWA) proposes four methods of leakage management [9]: Active Leakage Control, Pipeline and Assets Management, Speed and Quality of Repairs and Pressure Management. An analysis of water losses in a distribution system on the basis of the IWA balance should be an integral part of the management and should precede the decisions on repairing or modernizing a water network.

The aim of the paper is to analyze of water losses in two middle-sized water distribution systems during the period of 10 years $(2005-2014)$. The obtained values of the performance indicators enabled to evaluate the condition of the systems.

* Corresponding author: a.musz@,wis.pol.lublin.pl 


\section{Materials and methods}

The first stage of our investigations involved acquiring operating data from the water companies in two towns - A and B. Part of the data that were not measured by a company and could not be determined exactly, were estimated on the basis of literature or on the basis of a network operator's experience. The acquired data were used to create a simplified IWA water balance and to calculate selected performance indicators of water losses. An analysis of the calculation results enabled to evaluate the condition of the water networks.

\subsection{Description of the networks}

Two analysed water distribution systems are located in middle-sized towns (A and B) in the eastern part of Poland. The parameters shown in Table 1 bear a strong resemblance to both systems. However, the system in town A is slightly bigger, which is reflected in the volume of water pumped from intakes and sold to customers as well as in the values of Water Network Intensity Indicator calculated as:

$$
W N I I=\frac{S I V}{L_{m}}
$$

where: $S I V$ - System Input Volume expressed as $\mathrm{m}^{3} / \mathrm{day}, L_{m}-$ length of mains $[\mathrm{km}]$.

Table 1. Characteristics of the water distribution systems at the end of 2014.

\begin{tabular}{|c|c|c|}
\hline Parameter & Town A & Town B \\
\hline Length of mines [km] & 83.04 & 70.20 \\
\hline Number of connections [pcs.] & 3996 & 3834 \\
\hline Length of connections [km] & 77.68 & 54.38 \\
\hline Population [person] & 29018 & 22463 \\
\hline Average operating pressure $[\mathrm{MPa}]$ & 0.39 & 0.30 \\
\hline Water Network Intensity Indicator $(W N I I)\left[\mathrm{m}^{3} / \mathrm{day} / \mathrm{km}\right]$ & 49.18 & 47.02 \\
\hline
\end{tabular}

The material structure of the networks is different. In the first network (town A), plastic pipes (PVC-U - 46\% and PE-HD - 12\%) and cast iron (31\%) predominate; $11 \%$ of pipes is made of asbestos-cement (A-C). The network in town $\mathrm{B}$ is made of cast iron $(34 \%)$, A-C (31\%), plastics (PVC-U - 23\% and PE-HD - 4\%) and steel (8\%).

\subsection{Calculations of water loss performance indicators}

A simplified IWA water balance constituted the basis for calculating the indicators of water losses, as shown in Table 2. The values of SIV and BAC for both systems, as well as $U A C$ for the system in town A were obtained from the water companies. $U A C$ for the system in town B was assumed as $6000 \mathrm{~m}^{3} / \mathrm{yr}$, according to the information obtained from the network operator. $A L$ were calculated as a sum of Unauthorised Consumption $(U C)$ and Customer Metering Inaccuracies $(C M I)$. $U C$ and $C M I$ were assumed according to literature [10-11] as $2 \%$ and $3 \%$ of $S I V$, respectively. $R L$ were calculated as a difference between $S I V$ and the other three components of the balance shown in Table 2. 
Table 2. Components of a simplified IWA water balance.

\begin{tabular}{|c|c|c|c|}
\hline \multicolumn{4}{|c|}{ System Input Volume (SIV) } \\
\hline Billed Authorised & Unbilled Authorised & Apparent Losses $(A L)$ & Real Losses $(R L)$ \\
Consumption $(B A C)$ & Consumption $(U A C)$ & .
\end{tabular}

To evaluate water losses, performance indicators recommended by IWA and commonly used in Poland were calculated, including Real Losses Level per connection per day $(R L L)$, Infrastructure Leakage Index (ILI) and Non-Revenue Water Level (NRWL). The first indicator was determined according to the formula:

$$
R L L=\frac{C A R L}{N_{c}}
$$

where CARL - Current Annual Real Losses corresponding to $R L$ from an IWA water balance expressed as $\mathrm{dm}^{3} /$ day, $N_{c}$ - number of service connections.

Infrastructure Leakage Index $(I L I)$ is defined as:

$$
I L I=\frac{C A R L}{U A R L}
$$

where $U A R L$ - Unavoidable Annual Real Losses [ $\mathrm{dm}^{3} /$ day], calculated according to the equation:

$$
U A R L=\left[18 \cdot L_{m}+25 \cdot L_{c}+0.8 \cdot N_{c}\right] \cdot P
$$

where $L_{c}$ - average distance from property line to a customer meter [km], in Poland usually corresponding to the length of connections, $P$ - average operating pressure head $\left[\mathrm{m} \mathrm{H}_{2} \mathrm{O}\right]$.

Non-Revenue Water Level (NRWL) was calculated as percent of SIV according to formula:

$$
N R W L=\frac{S I V-B A C}{S I V} \cdot 100 \%
$$

The obtained performance indicators results for two systems in question were analysed and used to evaluate the condition of systems according to World Bank Institute Physical Loss Assessment Matrix (Tab. 3) [12]. The values of indicators were also compred to literature data for similar systems in Poland.

Table 3. Components of a simplified IWA water balance.

\begin{tabular}{|c|c|c|c|c|c|}
\hline \multirow{2}{*}{$\begin{array}{c}\text { Technical Performance } \\
\text { Category }\end{array}$} & \multirow{2}{*}{$\boldsymbol{I L I}$} & \multicolumn{4}{|c|}{$\boldsymbol{R} \boldsymbol{L} \boldsymbol{L}\left[\mathbf{d m}^{\mathbf{3}} / \mathbf{c o n n e c t i o n} / \mathbf{d a y}\right]$ at an average pressure of: } \\
\cline { 3 - 6 } & $\mathbf{2 0 m}$ & $\mathbf{3 0 m}$ & $\mathbf{4 0 m}$ & $\mathbf{5 0 m}$ \\
\hline A & $1-2$ & $<50$ & $<75$ & $<100$ & $<125$ \\
\hline B & $2-4$ & $50-100$ & $75-150$ & $100-200$ & $125-250$ \\
\hline C & $4-8$ & $100-200$ & $150-300$ & $200-400$ & $250-500$ \\
\hline D & $>8$ & $>200$ & $>300$ & $>400$ & $>500$ \\
\hline
\end{tabular}




\section{Results and discussion}

Tables 4 and 5 show the components of simplified IWA water balances for towns A and $\mathrm{B}$, necessary to calculate the selected water loss performance indicators.

The values of $S I V$ in both systems remained stable during the analyzed period. The difference between the highest and the lowest value for the first system (town A) equaled $144628 \mathrm{~m}^{3} / \mathrm{yr}$, which is $10.8 \%$ of average $S I V$ in the period. The corresponding values for the second system (town B) are $113200 \mathrm{~m}^{3} / \mathrm{yr}$ and $9.4 \%$. The average values of $S I V$ for both systems are comparable - the relative difference (related to the first system) equaled less than $16 \%$.

Table 4. Components of the water balance for the system in town A over the period 2005-2014, expressed in $\mathrm{m}^{3} / \mathrm{yr}$.

\begin{tabular}{|c|c|c|c|c|c|}
\hline Year & $S I V$ & $B A C$ & $U A C$ & $A L$ & $R L$ \\
\hline 2005 & 1516038 & 1275684 & 68158.0 & 75801.9 & 96394.1 \\
\hline 2006 & 1481882 & 1304421 & 72566.0 & 74094.1 & 30800.9 \\
\hline 2007 & 1438227 & 1268594 & 54307.7 & 71911.4 & 43414.0 \\
\hline 2008 & 1438180 & 1230961 & 73702.7 & 71909.0 & 61607.3 \\
\hline 2009 & 1459074 & 1166664 & 118491.7 & 72953.7 & 100964.6 \\
\hline 2010 & 1408449 & 1204796 & 76734.6 & 70422.5 & 56496.0 \\
\hline 2011 & 1445893 & 1227401 & 80564.7 & 72294.7 & 65632.7 \\
\hline 2012 & 1397690 & 1217792 & 69171.9 & 69884.5 & 40841.6 \\
\hline 2013 & 1392010 & 1190144 & 63078.2 & 69600.5 & 69187.3 \\
\hline 2014 & 1361410 & 1133267 & 62297.3 & 68070.5 & 97775.2 \\
\hline
\end{tabular}

The values of $R L L$ for systems in towns $\mathrm{A}$ and $\mathrm{B}$ are shown in Fig. 1. In each year over the period 2005-2014, RLL for the first system was higher than for the second one, with a slight difference in 2007 and the highest discrepancy in 2009. The first system was characterized by $R L L$ varying over a wide range (from $78.17 \mathrm{dm}^{3} /$ connection/day to $126.59 \mathrm{dm}^{3} /$ connection/day) during the whole analyzed period. For the second system, after $2007 R L L$ appreciable reduced from more than $80 \mathrm{dm}^{3} /$ connection/day to less than $40 \mathrm{dm}^{3} /$ connection/day and in the second half of the period in question, it remained stable (about $60 \mathrm{dm}^{3} /$ connection/day). The values of $R L L$ indicate Category A according to WBI Target Matrix (Tab. 3) over the majority of years in the analyzed period (excluding 2005, 2009 and 2014) for the first system and after 2007 for the second system, which means that further loss reduction may be uneconomic in the systems. 
Table 5. Components of the water balance for the system in town B over the period 2005-2014, expressed in $\mathrm{m}^{3} / \mathrm{yr}$.

\begin{tabular}{|c|c|c|c|c|c|}
\hline Year & $S I V$ & $B A C$ & $U A C$ & $A L$ & $R L$ \\
\hline 2005 & 1271800 & 1023164 & 6000 & 50872 & 171067 \\
\hline 2006 & 1255700 & 1092502 & 6000 & 50228 & 88505 \\
\hline 2007 & 1234500 & 1047422 & 6000 & 49380 & 118124 \\
\hline 2008 & 1182700 & 1066423 & 6000 & 47308 & 49546 \\
\hline 2009 & 1165900 & 1043028 & 6000 & 46636 & 58476 \\
\hline 2010 & 1193600 & 1053277 & 6000 & 47744 & 74690 \\
\hline 2011 & 1197100 & 1057341 & 6000 & 47884 & 76980 \\
\hline 2012 & 1206700 & 1065872 & 6000 & 48268 & 80486 \\
\hline 2013 & 1194500 & 1062548 & 6000 & 47780 & 69372 \\
\hline 2014 & 1158600 & 1017788 & 6000 & 46344 & 81677 \\
\hline
\end{tabular}

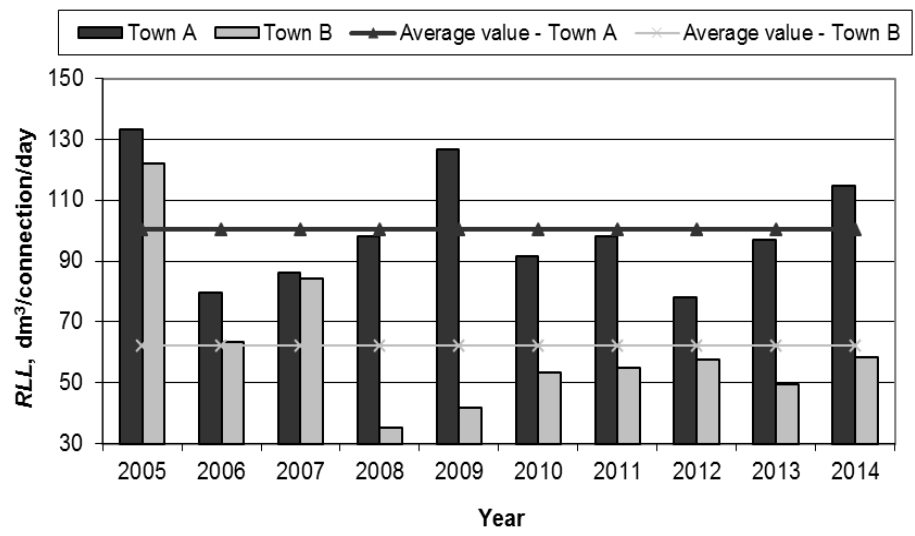

Fig. 1. Operational indicator $R L L$.

The values of $I L I$ shown in Fig. 2 correspond to the values of $R L L$. For the first system, $I L I$ exceeded 1.5 in 2005, 2009 and 2014, whereas for the rest of the period in question it was in the range of 1-1.5. For the second system, in the first 3 years of the period, ILI was clearly higher than in the first system, reaching the values between 1.8 and 3.6. In 2008 for the second system, ILI fell to the value of 1.0 and since 2010 it has remained stable (about 1.5) and comparable with the values for the first system. The values of ILI lower than 2 indicate Category A, according to WBI Target Matrix (Tab. 3), over the whole period in question for the first system (unlike for $R L L$ ) and after 2007 for the second system (like for $R L L)$ as well. It should be emphasized that $U A R L$ used in the calculation of $I L I$, is a reliable predictor for a system with more than 5000 service connections, density of connections greater than 20 per km of mains and average operating pressure greater than $25 \mathrm{~m} \mathrm{H}_{2} \mathrm{O}$ [13-15], and the first of these conditions is not met by any system in question. However, on 
the basis of tests and the analysis, the guidelines for New Zealand [16] recommend reducing this limitation by replacing 3 conditions by a single one: UARL calculation should be reliable, if $\left(L_{m} \cdot 20+N_{c}\right)$ exceeds 3000 . This condition is met by both systems in question.

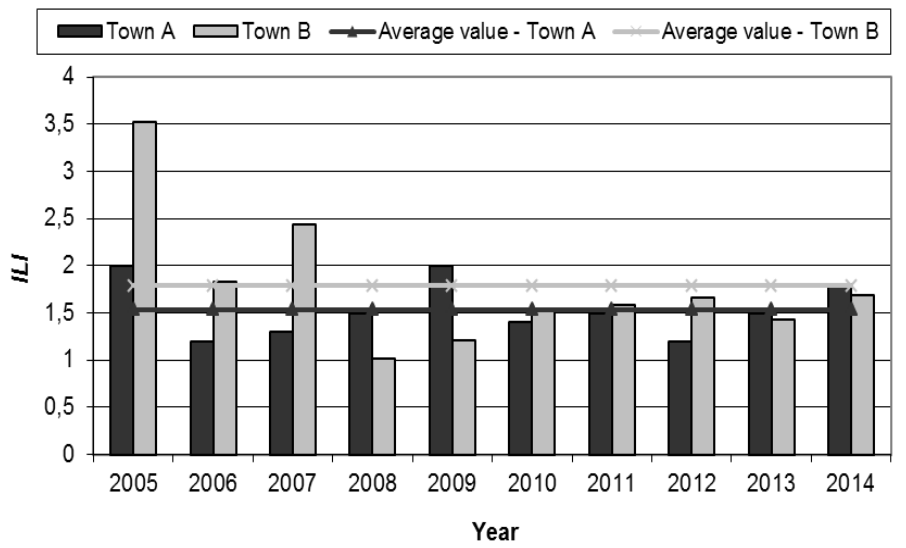

Fig. 2. Operational indicator $I L I$.

The values of $N R W L$ (Fig. 3) are higher for the first system in all but 2 years (2005 and 2009 ) of the period in question. Similarly to the previous indicators, $N R W L$ varied in a wide range in the whole period as far as the first system is concerned, whereas for the second system, it remained stable after 2007.

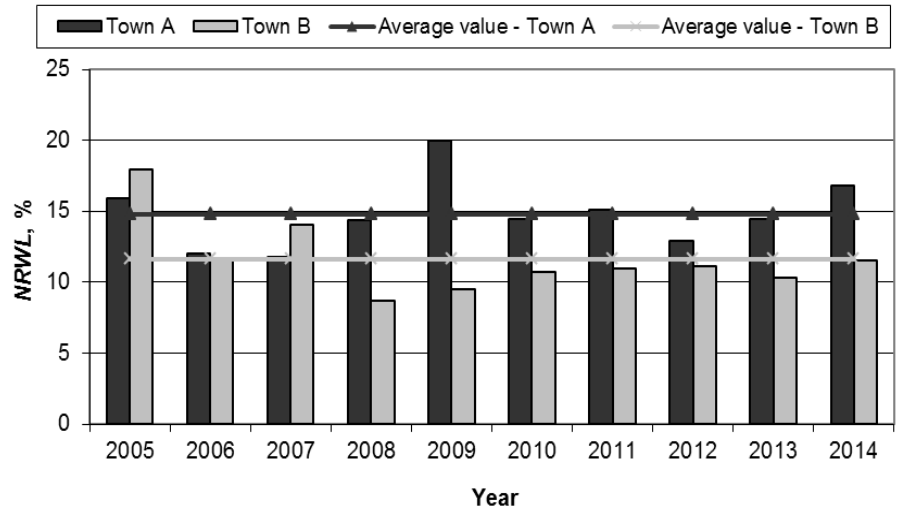

Fig. 3. Financial indicator $N R W L$.

An increased awareness of the significance related to losses management, which has occurred in Poland over the last decade, made calculating water losses performance indicators a popular practice [e.g. 17-22]. Table 6 presents the published average values of $R L L, I L I$ and $N R W L$ for Polish water distribution systems, similar to the examined systems according to WNII (formula (1)) or/and population. The values given in Table 6 indicate that water losses in the water systems of towns A and B are definitely the lowest in comparison with other towns. Moreover, $N R W L$ for the city of Kos in Greece (population of ca. 17350 from September to February, and ca. 40000 from March to August) ranges from 10.7 to 63.7 during the period 1999-2008 [23], significantly exceeding the values calculated for the towns A and B. The results of comparison between the considered Polish towns, other Polish towns described in the literature, and the Greek city can suggest a very 
good condition of the examined systems, but may also be a cause of doubt pertaining to the accuracy of the estimated components of water balances, necessary to determine the water losses indicators.

Table 6. Water losses in water distribution systems in selected Polish towns.

\begin{tabular}{|c|c|c|c|c|c|c|}
\hline Town & $W N I I$ & Population & $R L L$ & $I L I$ & $N R W L$ & Literature \\
\hline- & {$\left[\mathrm{m}^{3} / \mathrm{day} / \mathrm{km}\right]$} & - & {$\left[\mathrm{dm}^{3} /(\right.$ connection/day) $]$} & {$[-]$} & {$[\%]$} & - \\
\hline Sanok & 40.35 & 39569 & 625.83 & 10.28 & 40.2 & {$[24]$} \\
\hline Myszków & 30.68 & 32499 & 159.78 & 2.26 & 27.2 & {$[25]$} \\
\hline Krosno & 38.30 & 47307 & 889.3 & 7.3 & - & {$[26]$} \\
\hline Jasło & 47.01 & 36363 & 362.9 & 5.0 & 20.3 & {$[27]$} \\
\hline Mielec & 47.17 & 60827 & 124.20 & 1.83 & 24.30 & {$[28]$} \\
\hline Town A & $\mathbf{4 9 . 1 8}$ & $\mathbf{2 9 0 1 8}$ & $\mathbf{1 0 0 . 3 4}$ & $\mathbf{1 . 5 4}$ & $\mathbf{1 4 . 7}$ & - \\
\hline Town B & $\mathbf{4 7 . 0 2}$ & $\mathbf{2 2 ~ 4 6 3}$ & $\mathbf{6 2 . 0 9}$ & $\mathbf{1 . 7 9}$ & $\mathbf{1 1 . 6 5}$ & - \\
\hline
\end{tabular}

\section{Conclusions}

The analysis of water losses in two middle-sized water distribution systems in towns $\mathrm{A}$ and $\mathrm{B}$ during the period of 10 years suggests their very good condition. The results indicate an improvement in the managing the system of town B after 2007, which was confirmed by the system operator and involved, i.a., reduction of the operating pressure. Average values of the calculated performance indicators were higher in the case of town A, but both can be classified as systems which do not require a further loss reduction according to WBI Loss Target Matrix. The comparison with other water distribution systems also indicates a good condition of the examined networks. However, the ultimate conclusion should be preceded by reinvestigating water losses in the networks in towns $\mathrm{A}$ and $\mathrm{B}$ on the basis of the IWA water balances with a reduced number of estimated components.

Real water losses are strongly connected with leakages occurring during breakages or failures of a network. In Polish water distribution systems, including systems in tows A and $\mathrm{B}$, they results mainly from the age of pipes, annual range of temperature, freezing of ground, unstable foundation and human mistakes during designing and construction of a network. The activities undertaken to reduce water losses include renewal or replacement of old pipes, optimization procedures for pressure control, detection and location of leakages, operational repairs. However, the activities results are not always sufficient, so it is recommended to supplement the investigation of water losses on the basis of the IWA water balances in the examined systems by failures analysis, to facilitate assessment of the systems conditions and formulating the ultimate conclusion. Thus, reinvestigating water losses in the networks in towns $\mathrm{A}$ and $\mathrm{B}$ with a reduced number of estimated water balances components, as well as the networks failure analysis will be the subject of our future investigations. 


\section{References}

1. D. Kowalski, K. Miszta-Kruk, Eng. Fail. Anal. 35, 736-742 (2003)

2. M. Kutyłowska, H. Hotloś, Eng. Fail. Anal. 41, 23-29 (2014)

3. M. Iwanek, D. Kowalski, M. Kwietniewski, Ochrona Środowiska 37(4), 13-17 (2015)

4. M. Kutyłowska, Period. Polytech. Civil. Eng. 59(1), 37-43 (2015)

5. M. Kutyłowska, Eng. Fail. Anal. 47, 41-48 (2015)

6. P. Suchorab, B. Kowalska, D. Kowalski, Rocznik Ochrona Środowiska 18(2), 416-427 (2016)

7. M. Iwanek, B. Kowalska, E. Hawryluk, K. Kondraciuk, Eksploatacja i Niezawodnosc Maitenance and Reliability 18 (2), 278-284 (2016)

8. M. Iwanek, P. Suchorab, M. Karpińska-Kiełbasa, Period. Polytech. Civil. Eng. Paper No 9728 (2017) (to be published)

9. A. Lambert, Water 21, 50-51 (2003)

10. G. Merlo, IWSA Workshop (Warszawa 1992)

11. T. Bergel, Gaz, Woda i Technika Sanitarna 8, 322-325 (2012)

12. R. Liemberger, K. Brothers, A. Lambert, R. McKenzie, A. Rizzo and T. Waldron, Water Loss Conference 1 (Bucharest, Romania, 2007)

13. A. Lambert, R. McKenzie, Proceedings of IWA Conference-Leakage Management: A Practical Approach (Lemesos, Cyprus 2002)

14. W. Winarni, Civil. Eng. Dimension 11(2), 126-134 (2009)

15. C. Lenzi, C. Bragalli, A. Bolognesi, M. Fortini, Procedia. Engin. 70, 1017-1026 (2014)

16. R. McKenzie, A. Lambert Benchmarking of Water Losses in New Zealand. Manual. (2008)

17. M. Kwietniewski, Ochrona Środowiska 35(4), 9-16 (2013)

18. A. Choma, M. Iwanek, B. Kowalska, D. Kowalski, Instal 10, 61-65 (2014)

19. J. Rak, D. Trojnar, Czasopismo Inżynierii Lądowej, Środowiska i Architektury XXXI, 61 1(14), 245-256 (2014)

20. K. Pietrucha-Urbanik, B. Tchórzewska-Cieślak: Journal of KONBiN. 1(33), 233-242 (2015)

21. M. Iwanek, A. Musz-Pomorska, B. Kowalska, D. Kowalski, M. Chołody, Instal 1(369), 40-43 (2016)

22. A. Musz-Pomorska, M. Iwanek, P. Suchorab, A. Brodaczewska, JCEEA. 1(I/16), 179-189 (2016)

23. V. Kanakoudis, S. Tsitsifli, Urban Water 7(5), 267-285 (2010)

24. I. Piegdoń, B. Tchórzewska-Cieślak, Gaz, Woda i Technika Sanitarna 10, 450-452 (2012)

25. W. Kędzia, E. Ociepa, Inżynieria i Ochrona Środowiska 18(4), 525-535 (2015)

26. K. Pietrucha-Urbanik, A. Studziński, Gaz, Woda i Technika Sanitarna 10, 452-454 (2012)

27. J. Rak, Ł. Sypień, JCEEA. 3(13), 5-18 (2013)

28. K. Kujawska, J. Rak, JCEEA. 2(I/16), 445-454 (2016) 